\title{
Isolation and Preliminary Characterization of a Spiroplasma from Coconut Palms in Jamaica
}

\author{
By S. J. EDEN-GREEN*† AND HENRY WATERS \\ UK Overseas Development Administration Lethal Yellowing Team, Coconut Industry \\ Board, Box 204, Kingston 10, Jamaica
}

(Received 25 September 1980; revised 5 January 1981)

\begin{abstract}
Isolation of spiroplasmas from healthy and lethal yellowing-diseased coconut palms was attempted by passaging inoculum from palm tissues in a lactalbumin hydrolysate-based medium for up to 12 serial blind subcultures. Spiroplasmas were isolated in two initial experiments but these results could not be repeated in extensive further tests. Isolates grew well in conventional mycoplasma and spiroplasma media and showed cultural and morphological characteristics typical of the genus Spiroplasma. Serological tests and electrophoretic analysis of cell protein preparations showed that the isolates differed from Spiroplasma citri and the Corn Stunt spiroplasma. The trivial name Cocos spiroplasma is proposed to distinguish this organism which is represented by a reference strain, ATCC 33287.
\end{abstract}

\section{INTRODUCTION}

Previous attempts to culture mycoplasma-like organisms (MLO) associated with lethal yellowing disease of coconut palms (Cocos nucifera $\mathrm{L}$.) have been unsuccessful (Eden-Green, 1978; McCoy, 1978). Several strains of Acholeplasma spp. were isolated from, or adjacent to, necrotic, rotting tissues of diseased palms (Eden-Green \& Tully, 1979) but pathogenicity tests (Eden-Green et al., 1980) and enzyme-linked immunosorbent assay (ELISA) of diseased tissues (Dollet et al., 1980; Townsend et al., 1980) indicated that these organisms were not the causal agents. The apparent non-cultivability of the presumed MLO pathogen of lethal yellowing accords with experience in most other plant yellows diseases (McCoy, 1979). Where isolation of the pathogen has been well established, as in citrus stubborn and corn stunt diseases, the causal agents have proved to be spiroplasmas (Markham et al., 1974; Chen \& Liao, 1975; Williamson \& Whitcomb, 1975). However, the significance of recent reports that describe the isolation of spiroplasmas from plants affected by other diseases is less clear (Kondo et al., 1977; Nyland \& Raju, 1978; Raju \& Nyland, 1978). A notable feature of the isolations described by Nyland \& Raju (1978) and Raju \& Nyland (1978) was the use of extensive serial blind passaging, and their results encouraged us to attempt further isolations by similar techniques. This report describes the initial success and subsequent failure of attempts to isolate spiroplasmas from coconut palms and gives preliminary characteristics of the isolates obtained.

\section{METHODS}

Plant material. Lethal yellowing-diseased and healthy coconut tissues were sampled from the crowns of palms as described by Eden-Green \& Tully (1979). With the exception of a pilot experiment (experiment 1), all samples from diseased palms were matched by equivalent healthy material and were coded and randomized by an independent observer so that isolations were carried out blind. Tissues sampled consisted of $10 \mathrm{~cm}$ lengths of inflorescence spike, removed immediately below blackened tips of unopened inflorescences (the internal necrosis

† Present address: Plant Pathology Department, Rothamsted Experimental Station, Harpenden, Herts. AL5 2JQ. 
that develops within unopened inflorescence spathes is initially microbiologically sterile; Grylls \& Hunt, 1971), and similar lengths of the rachis of up to four expanding leaves younger than the youngest visible leaf emerging from the intact crown. Rachis sections were selected immediately above the short region of actively expanding leaf tissues, usually within $20 \mathrm{~cm}$ above the growing point. Electron-microscope observations have shown both regions to be particularly rich in MLO (H. Waters, unpublished results). All tissue samples were free of external necrosis and were surface-sterilized for $10 \mathrm{~min}$ in $10 \%(\mathrm{v} / \mathrm{v})$ hypochlorite solution followed by six rinses in sterile distilled water.

Media and isolation techniques. Isolations from coconut tissues were carried out in a lactalbumin hydrolysate-based liquid medium developed by B. C. Raju (personal communication; Department of Plant Pathology, University of California, Davis, California 95616, U.S.A.). The medium was modified from and was qualitatively similar to the leafhopper tissue culture medium of Chiu \& Black (1967) and had a final pH of 7.6 and osmolality of 275 mosmol kg-1. A biphasic medium used in addition to or in place of the above was prepared by adding complete liquid medium to 1 to $2 \mathrm{ml}$ slopes of the same medium supplemented with $1 \%(\mathrm{w} / \mathrm{v}$ ) agar (Difco) and a suspension of $1 \%(\mathrm{w} / \mathrm{v})$ activated charcoal $(\mathrm{BDH})$ and $0.2 \%(\mathrm{w} / \mathrm{v})$ manganese dioxide (after Butler \& Knight, 1960). Some isolations were also attempted in C3 and C4 medium (described below). All media were dispensed in approximately $5 \mathrm{ml}$ portions in sterile vials (Sterilin 129A). To inoculate media, 10 to 12 transverse slices of palm tissue ( 0.5 to $1 \mathrm{~mm}$ thick) were cut in 12 to $15 \mathrm{ml}$ of complete medium, allowed to stand for $1 \mathrm{~min}$, and about $0.5 \mathrm{ml}$ of the resulting suspension was filtered through a $0.45 \mu \mathrm{m}$ pore-size filter (Millipore MF) into duplicate vials of culture medium. Vials were incubated at 29 to $30^{\circ} \mathrm{C}$ and $0.5 \mathrm{ml}$ of each was subcultured to fresh medium at 2 to $4 \mathrm{~d}$ intervals for up to 12 serial blind passages. Subcultures were carried out in a set sequence using an automatic pipette (Finnpipette) with unplugged sterile tips. With the exception of the first, each experiment consisted of duplicate vials prepared from each of two samples from each of two or four diseased palms, comparable healthy material and a pair of uninoculated medium controls.

Vials showing a change in $\mathrm{pH}$ (as shown by the internal phenol red indicator), and random samples of all other vials were examined by dark-field light microscopy at $1200 \times$ magnification. Cultures suspected to be spiroplasmas were subcultured and lyophilized.

Preliminary characterization. As earlier experiments had shown that the lactalbumin hydrolysate-based medium supported only poor to moderate growth of $S$. citri, and little or no growth of the Corn Stunt spiroplasma, most comparative tests utilized a modification of Chen \& Liao's (1975) C3 medium. This contained $0.4 \%(\mathrm{w} / \mathrm{v})$ yeastolate (Difco) instead of fresh yeast extract, 20 p.p.m. phenol red, 1.0\% (v/v) CMRL 1066 medium (Gibco) and 7.5 to $15 \%(\mathrm{v} / \mathrm{v})$ serum (see below); final pH 7.6, osmolality about $860 \mathrm{mosmol} \mathrm{kg} \mathrm{kg}^{-1}$. Solidified medium was prepared by incorporating Difco agar in the basal medium to a final concentration of $1.1 \%(\mathrm{w} / \mathrm{v})$. Other media used were the above modified C3 medium with the sucrose concentration reduced to $8 \%$ (w/v) $\left(530 \mathrm{mosmol} \mathrm{kg}^{-1}\right.$; designated C4 medium), 7\% (w/v) sorbitol (SMC) medium (730 mosmol kg ${ }^{-1}$; Saglio et al., 1971), and conventional mycoplasma medium ( 300 mosmol kg ${ }^{-1}$; Hayflick, 1965). Foetal bovine serum was used in most media, at concentrations ranging from 7.5 to $15 \%(\mathrm{v} / \mathrm{v})$, but was substituted in some tests by untreated horse serum or the supernatant from horse serum precipitated with 2 vol. chloroform (Cotty \& Chen, 1979) or 1 vol. saturated $\left(\mathrm{NH}_{4}\right)_{2} \mathrm{SO}_{4}$, and dialysed against $1.15 \%(\mathrm{w} / \mathrm{v}) \mathrm{KCl}$. Media were also prepared using $1 \%(\mathrm{v} / \mathrm{v})$ serum fraction (Difco) in place of serum. All sera were heated at $55^{\circ} \mathrm{C}$ for $1 \mathrm{~h}$ before use.

Essential characteristics of mollicutes, including cellular and colony morphology, ultrastructure, filtrability and absence of reversion to bacterial forms (International Committee on Systematic Bacteriology, Subcommittee on the Taxonomy of Mollicutes, 1979) were examined during triple filter cloning of three isolates, using penicillin-free media. Two uncloned isolates and one or two clones derived from each, were selected for more detailed comparison with S. citri (citrus stubborn agent, NCPPB 2565) and Corn Stunt spiroplasma (ATCC 29320), which were the only other spiroplasmas in culture at this laboratory. Dependence on serum for growth was tested by plating organisms on $\mathrm{C} 4$ agar prepared with $15 \%(\mathrm{v} / \mathrm{v})$ foetal bovine serum or without serum, and sensitivities to digitonin and sodium polyanethol sulphonate were determined by disc tests (Freundt et al., 1973) on the same $15 \%$ serum medium. Antisera were raised in rabbits against uncloned isolates (commenced before clones were available). To prepare antigens, cultures were grown in $500 \mathrm{ml}$ medium, centrifuged $(30 \mathrm{~min}, 20000 \mathrm{~g})$, washed twice in phosphate-buffered saline [PBS; $0.8 \%(\mathrm{w} / \mathrm{v}) \mathrm{NaCl}, 0.02 \%(\mathrm{w} / \mathrm{v}) \mathrm{KH}_{2} \mathrm{PO}_{4}, 0.115 \%(\mathrm{w} / \mathrm{v}) \mathrm{Na}_{2} \mathrm{HPO}_{4}$, $0.02 \%(\mathrm{w} / \mathrm{v}) \mathrm{KCl}$ containing $10 \%(\mathrm{w} / \mathrm{v})$ sucrose and resuspended in $2.5 \mathrm{ml}$ PBS. Two intramuscular injections were given at an interval of 2 weeks using $1 \mathrm{ml}$ of this suspension emulsified in $1 \mathrm{ml}$ of Freund's complete adjuvant (1st injection) and incomplete adjuvant (2nd injection), followed 1 week later by one intravenous injection of 0.5 $\mathrm{ml}$ suspension and bleeding after a further week. Antisera were prepared by similar techniques against $S$. citri and the Corn Stunt spiroplasma; these gave the same qualitative reactions as samples of specific antisera donated by $\mathbf{R}$. Townsend and J. G. Tully. Two antisera against the spiroplasmas claimed to be associated with aster yellows and western-X diseases were received from B. C. Raju and were included in some tests, but cultures of these organisms were not available to us. Antigenic relationships were compared by a simplified combined deformation and metabolic inhibition test (Williamson et al., 1978; Williamson et al., 1979), using twofold dilutions of antisera and single dilutions of antigens, both prepared in $\mathrm{C} 3$ medium containing $2 \%$ (v/v) guinea pig complement (Gibco), and by growth inhibition tests (Clyde, 1964) on C4 agar. 
For comparison of polyacrylamide gel electrophoresis (PAGE) banding patterns, spiroplasmas were centrifuged (30 min, $20000 \mathrm{~g}$ ) from up to $500 \mathrm{ml}$ of 7 to $10 \mathrm{~d}$ cultures grown in C3 medium, and washed twice in PBS containing $10 \%(\mathrm{w} / \mathrm{v})$ sucrose. Whole cell proteins were separated through polyacrylamide $(7.5 \%, \mathrm{w} / \mathrm{v}$, acrylamide) in the presence of sodium dodecyl sulphate (SDS) (after Markham et al., 1974), using a $20 \mathrm{~cm}$ slab gel apparatus (Raven Scientific. Ltd, Haverhill, Suffolk) run at $15 \mathrm{~mA}$ per gel.

\section{RESULTS}

\section{Isolation of spiroplasmas}

Isolations were attempted in duplicate from 33 tissue samples from 16 diseased palms and 28 samples from 14 healthy palms, in seven experiments (Table 1). Spiroplasmas were isolated at passage 7 and at passages 4 and 10 in experiments 1 and 2, but intensive efforts to repeat these early results were unsuccessful. As indicated in Table 1, some isolations in experiment 2 occurred in passage series that derived from both diseased and healthy palms and, in one instance, from a vial of the uninoculated control medium. As these isolates were in a short sequence of seven vials out of 35 subcultured at passage 4, we consider it likely that the observed distribution of spiroplasmas resulted from accidental contamination of the automatic pipette nozzle and subsequent transfer to successive cultures. Subcultures at passage 7 of experiment 1 and passage 4 of experiment 2 were, in fact, carried out consecutively on the same day, so it was possible that all isolates derived from a single diseased palm sample used in experiment 1. However, this explanation was less likely to account for the single isolate obtained at passage 10 (M208, see Table 1), which apparently originated from a healthy palm. Greater care was taken during manipulation of later subcultures but the build up of bacterial contaminants remained an occasional problem, particularly in a few isolations attempted in C 3 or C4 medium. No other mycoplasma-like structures were identified in cultures examined by light microscopy, although precipitated debris and spherical vesicles, probably derived from serum lipoproteins, were quite common in both control and inoculated media.

\section{Characteristics of isolates}

All spiroplasma isolates were readily subcultured in C3 medium and produced a greater and more rapid ( 3 to $5 \mathrm{~d}$ ) reduction in $\mathrm{pH}$, with larger numbers of helices, than in the original isolation medium. Maximal titres, as judged by direct enumeration of helices (Whitcomb \& Williamson, 1975), were about $8 \times 10^{8}$ helices $\mathrm{ml}^{-1}$, which was rather lower than those

\section{Table 1. Isolation of spiroplasmas in liquid and biphasic (liquid over agar) media during serial blind passage of coconut tissue samples}

\begin{tabular}{|c|c|c|c|c|c|c|c|c|}
\hline \multirow[b]{2}{*}{$\begin{array}{l}\text { Expt } \\
\text { no. }\end{array}$} & \multirow[b]{2}{*}{ Medium } & \multirow[b]{2}{*}{$\begin{array}{c}\text { No. of } \\
\text { passages }\end{array}$} & \multicolumn{2}{|c|}{ Diseased palms } & \multicolumn{2}{|c|}{ Healthy palms } & \multicolumn{2}{|c|}{ Control media } \\
\hline & & & $\begin{array}{c}\text { No. of } \\
\text { samples }\end{array}$ & $\begin{array}{l}\text { No. of } \\
\text { isolates* }\end{array}$ & $\begin{array}{c}\text { No. of } \\
\text { samples }\end{array}$ & $\begin{array}{l}\text { No. of } \\
\text { isolates* }\end{array}$ & $\begin{array}{c}\text { No. of } \\
\text { samples }\end{array}$ & $\begin{array}{c}\text { No. of } \\
\text { isolates* }\end{array}$ \\
\hline 1 & $\begin{array}{l}\text { Biphasic } \\
\text { Liquid }\end{array}$ & $\left.\begin{array}{l}7 \\
7\end{array}\right\}$ & 5 (2 palms) & $\begin{array}{l}0 \\
3^{a}\end{array}$ & $\begin{array}{l}0 \\
0\end{array}$ & - & $\begin{array}{l}2 \\
2\end{array}$ & $\begin{array}{l}0 \\
0\end{array}$ \\
\hline 2 & $\begin{array}{l}\text { Biphasic } \\
\text { Liquid }\end{array}$ & $\left.\begin{array}{r}8 \\
10\end{array}\right\}$ & 8 (4 palms) & $\left.\begin{array}{l}2^{b} \\
0\end{array}\right\}$ & 8 (4 palms) & $\begin{array}{l}2^{c} \\
1^{e}\end{array}$ & $\begin{array}{l}1 \\
1\end{array}$ & $\begin{array}{l}1^{d} \\
0\end{array}$ \\
\hline 3 & Biphasic & 12 & 4 (2 palms) & 0 & 4 (2 palms) & 0 & 2 & 0 \\
\hline 4 & Biphasic & 12 & 4 (2 palms) & 0 & 4 (2 palms) & 0 & 2 & 0 \\
\hline 5 & Biphasic & 12 & 4 (2 palms) & 0 & 4 (2 palms) & 0 & 2 & 0 \\
\hline 6 & Biphasic & 12 & 4 ( 2 palms $)$ & 0 & 4 (2 palms) & 0 & 2 & 0 \\
\hline 7 & Liquid & 12 & 4 (2 palms) & 0 & 4 (2 palms) & 0 & 2 & 0 \\
\hline
\end{tabular}

\footnotetext{
* Isolate codes: $a$ - L616, L620, L625 (each was one of a duplicate culture, passage 7); $b$ - L587, L590 (each was one of a duplicate culture, passage 4); c-L585, L592 (each was one of a duplicate culture, passage 4); $d$ - L591 (one only, passage 4); $e-$ M208 (one of a duplicate culture, passage 10).
} 
achieved by $S$. citri (at least $2 \times 10^{9}$ helices $\mathrm{ml}^{-1}$ ). The morphology and morphological changes during growth of all the isolates resembled those reported for $S$. citri (Cole et al., 1973), but the motility of the organisms was consistently less vigorous than that of both $S$. citri and the Corn Stunt spiroplasma, and exponential phase cultures showed a higher proportion of distorted or branched helices. Individuals showing both helical and non-helical regions were quite common (Fig. 1). The organisms appeared to grow equally well in conventional mycoplasma medium, suggesting tolerance to a wide range of osmotic conditions, but substitution of crude horse serum for foetal bovine serum induced marked clumping and distortion of helices and extensive precipitation during growth in media of both high and low osmotic pressure. These effects were very much more marked than with $S$. citri grown in the same batches of medium, but were reduced in media prepared with chloroformor $\left(\mathrm{NH}_{4}\right)_{2} \mathrm{SO}_{4}$-treated horse serum. Media containing $1 \%$ serum fraction in place of serum developed only slight acidity, accompanied by very low numbers of severely distorted helices.

Isolates produced both 'fried egg' colonies on the surface of agar media as well as pin-point downgrowths (Figs 2 and 3). Although colonies attained greater diameters on C3 or C4 agar (up to $400 \mu \mathrm{m}$ ), they developed equally rapidly, and to a similar density, on conventional mycoplasma agar. Cultures appeared to grow equally well at $30^{\circ} \mathrm{C}$ and $37^{\circ} \mathrm{C}$, as judged by the rate of acid production and colony development. Organisms passed $0.3 \mu \mathrm{m}$ pore-size membrane filters during cloning with estimated $10^{-1}$ to $10^{-2}$ reductions in titre, and ultrathin sections of organisms trapped in membrane filters showed typical wall-free mycoplasma ultrastructure and profile morphology (Figs 4 and 5). No reversion to bacterial forms occurred after five passages in penicillin-free medium.

Growth was not detected on agar media prepared without serum and a requirement for sterols was also indicated by digitonin inhibition zones comparable in size to those obtained with $S$. citri. In contrast, isolates were not inhibited around sodium polyanethol sulphonate discs on either C3 or conventional mycoplasma agar, whilst $S$. citri showed small ( 3 to $5 \mathrm{~mm}$ ) inhibition zones on the latter medium, as reported by Saglio et al. (1973).

In preliminary serological deformation tests, the paim isolates showed only partial deformation of helices at dilutions of antisera to the two spiroplasma reference cultures as low as 1 in 8 . These antigenic differences were confirmed in subsequent tests using heterologous combinations of both cloned and uncloned palm isolates, the two reference strains, and their specific antisera (Table 2). In all three tests, both cloned and uncloned isolates appeared to be identical and showed high homologous titres, but cross-reacted with $S$. citri antiserum only at low dilutions $(1: 16$ to $1: 32)$ in the deformation tests. These results were supported by metabolic inhibition titres, although it should be noted that metabolic inhibition values were considerably lower than would be expected in tests carried out at limiting dilutions of antigen (Williamson et al., 1979). All palm spiroplasma cultures were unaffected by normal (preimmune) serum at the lowest dilution tested $(1: 2)$. The aster yellows and western-X spiroplasma antisera showed significant activities against $S$. citri and the Corn Stunt spiroplasma, but not the palm isolates, in one-way deformation/metabolic inhibition tests, and the aster yellows antiserum gave similar results in the growth inhibition tests. A close serological relationship between these isolates and $S$. citri has been previously reported (Raju et al., 1980) but data were not provided. In some instances, growth of the Corn Stunt spiroplasma was actually stimulated around discs of the palm spiroplasma antiserum.

Comparison of PAGE banding patterns (Fig. 6) confirmed the similarities of all the cloned and uncloned palm isolates and further illustrated differences between these and the reference strains. Some bands with identical mobility appeared to be present but major bands present in $S$. citri were faint or absent in the palm spiroplasma preparations. Patterns obtained with $S$. citri and the Corn Stunt spiroplasma showed consistent differences in this buffer system. A triply cloned isolate designated N525 (a clone of isolate L625) was selected on the basis of serological and PAGE characteristics as representative of the palm isolates and has been deposited with the American Type Culture Collection (ATCC 33287). 

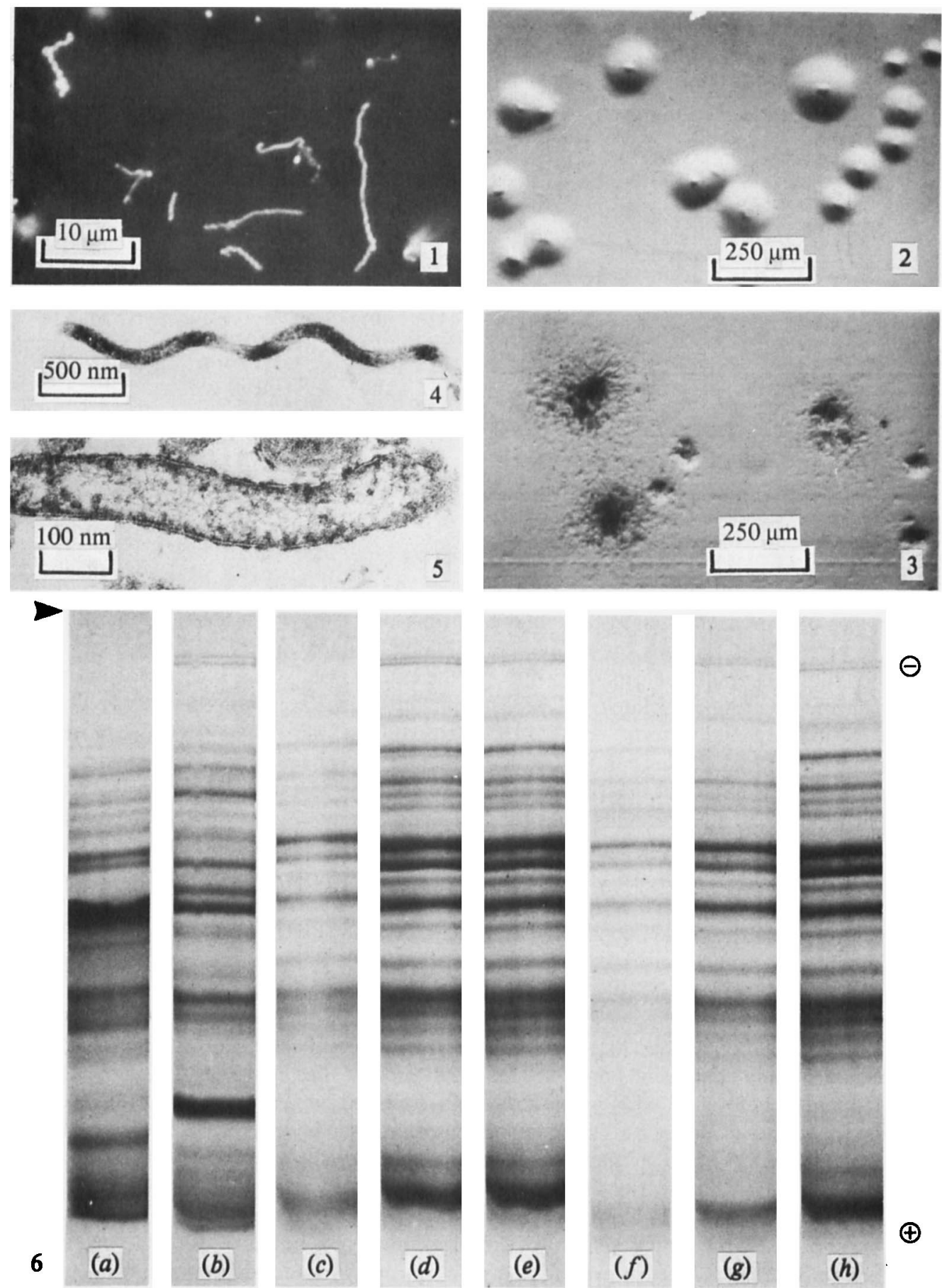

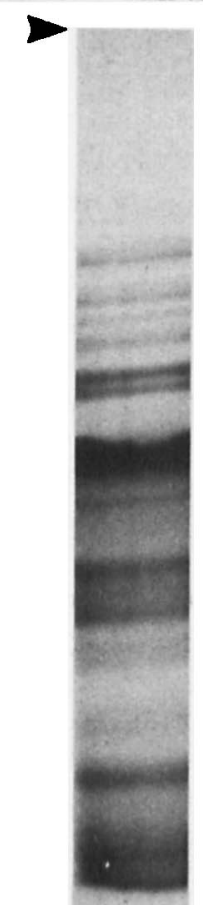

6

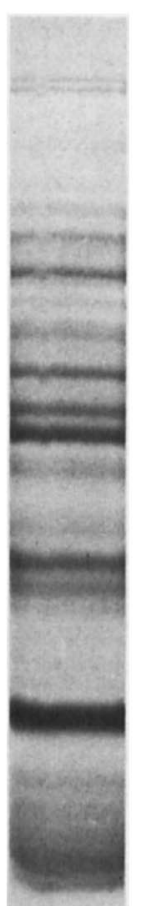

(b)
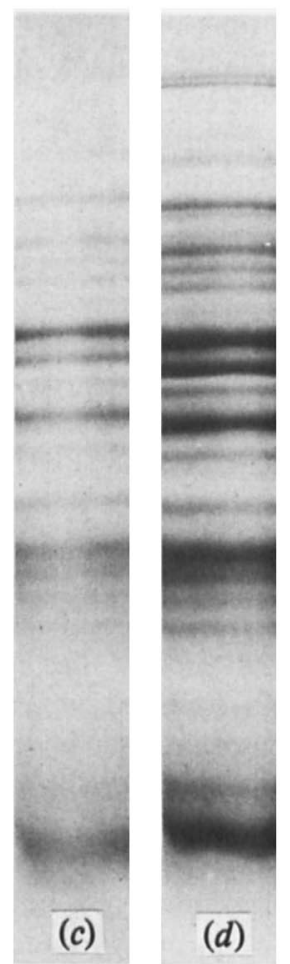

$\Theta$

$\oplus$

Fig. 1. Isolate L585 in lactalbumin hydrolysate-based liquid medium (dark field).

Figs 2 and 3. Colonies of isolates L592 and L625 on C4 agar dried for 5 min and 20 min, respectively ( $5 \mathrm{~d}$ incubation at $30^{\circ} \mathrm{C}$ ).

Figs 4 and 5. Ultrathin sections of isolate L625.

Fig. 6. Electrophoretic patterns of spiroplasma proteins: (a) Corn Stunt spiroplasma; (b) S. citri; (c) uncloned isolate L585; $(d, e)$ clones of isolate L585; $(f)$ uncloned isolate $\mathrm{L} 625 ;(g, h)$ clones of isolate L625. The arrow marks the origin. 
Table 2. Serological deformation/metabolic inhibition test titres and growth inhibition zones of palm spiroplasmas, S. citri, and Corn Stunt spiroplasma (CSS) against their antisera and antisera to aster yellows $(A Y)$ and western- $X(W-X)$ spiroplasmas

Deformation and metabolic inhibition test titres are reciprocal dilutions of antisera, shown as the fraction: deformation/metabolic inhibition. Values in parentheses are widths of growth inhibition zones, in $\mathrm{mm}$. Antigens were uncloned palm isolates L625 and L585 (see Table 1) and respective triply filtered clones, N525 and N628.

\begin{tabular}{|c|c|c|c|c|c|c|c|c|c|c|}
\hline \multirow{2}{*}{ Antigen } & \multicolumn{10}{|c|}{ Antiserum } \\
\hline & \multicolumn{2}{|l|}{ L625 } & \multicolumn{2}{|l|}{ S. citri } & \multicolumn{2}{|l|}{ CSS } & \multicolumn{2}{|l|}{ AY } & \multicolumn{2}{|l|}{ W-X } \\
\hline L625 & $4096 / 8192$ & (8) & $16 / 64$ & $(0)$ & $16 / 32$ & (0) & $32 / 64$ & $(0)$ & $32 / 64$ & $(-)$ \\
\hline N525 & $8192 / 8192$ & (8) & $32 / 32$ & (0) & $-1-$ & (0) & $-1-$ & (0) & $-1-$ & $(-)$ \\
\hline L585 & $8192 / 8192$ & (7) & $32 / 16$ & (0) & $16 / 32$ & (0) & $32 / 32$ & (0) & $16 / 16$ & $(-)$ \\
\hline N628 & $8192 / 2048$ & (8) & $32 / 32$ & (0) & $-1-$ & (0) & -1 & (0) & $-1-$ & $(-)$ \\
\hline S. citri & $16 / 16$ & (0) & $16384 / 4096$ & (8) & $512 / 128$ & (4) & $2048 / 512$ & (6) & $4096 / 512$ & $(-)$ \\
\hline CSS & $8 / 32$ & (0) & $128 / 1024$ & (2) & $4096 / 2048$ & (12) & $512 / 256$ & (3) & $512 / 512$ & $(-)$ \\
\hline
\end{tabular}

-, Not determined.

DIS CUSSION

The initial isolations of spiroplasmas from palms affected by lethal yellowing disease raised great hopes of a breakthrough in the lethal yellowing problem, which has been the subject of intensive research in Jamaica for many years. The subsequent failure of attempts to repeat this work suggests that these organisms are not the causal agents and, indeed, casts doubt on the origin of the original isolates; we expect that these questions may be answered by the results of pathogenicity tests and ELISA experiments, now in progress. A possible explanation for these findings is that initial isolation of spiroplasmas from palms is very difficult, and the isolates obtained represent an unlikely and fortuitous event. In this case, the apparent isolation of spiroplasmas from healthy palms and control media may have been due to cross-contamination during subculturing. We consider it unlikely that these isolates derived from contaminated growth medium constituents, as stringent precautions were taken to eliminate likely sources such as sera, and the isolates were distributed in a non-random sequence of culture vials. No Mycoplasma or Acholeplasma spp., which are known contaminants of commercial sera (Barile et al., 1978), have been encountered at this laboratory.

Demonstration that lethal yellowing is caused by a spiroplasma would clearly support the view that non-cultivable MLO associated with other plant yellows diseases may be spiroplasmas. Such conclusions are not justified at present, and must also be reconciled with the in vivo morphology of lethal yellowing MLO described by Waters \& Hunt (1980). These authors found no evidence for spiroplasmal morphology in a detailed analysis of serial ultrathin sections of MLO in sieve elements from lethal yellowing-diseased coconut roots. However, single ultrathin sections of spiroplasmas in infected insects (Townsend et al., 1977; Whitcomb \& Williamson, 1975) and occasionally in plants (Markham et al., 1977; Markham \& Townsend, 1979) have suggested that helical morphology is not always maintained in vivo.

Although our results have shown that the palm spiroplasmas differ from others in culture at this laboratory, many other strains of spiroplasmas have recently been isolated from diverse environments (Davis, 1979). Recent reports suggest that at least four serogroups can be distinguished on the basis of antigenic properties, and the two reference strains that we have investigated here represent only one of these groupings (Davis et al., 1979; Junca et al., 1980; Tully et al., 1980). Recent tests carried out by J. G. Tully (unpublished results) indicate that the coconut isolates show some relationships to the $277 \mathrm{~F}$ spiroplasma (originally isolated from rabbit ticks) in metabolic inhibition and growth inhibition (but not deformation) tests, 
and to the BC3 (honeybee) and LB12 (green leaf bug) spiroplasmas in metabolic inhibition tests. These results strongly suggest that the palm spiroplasmas represent a new subgroup in the $S$. citri complex, but further work is needed to explore the relationship of the palm isolates to other spiroplasma strains. For the time being, we propose the trivial term Cocos spiroplasma to distinguish these isolates, as represented by strain N525 (ATCC 33287).

This work formed part of the Lethal Yellowing of Coconuts Research Scheme (R3098) organized by the Coconut Industry Board, Jamaica with financial assistance from the Government of Jamaica and the United Kingdom Overseas Development Administration. We thank B. C. Raju for providing antisera and details of the medium and techniques used for isolating spiroplasmas.

\section{REFERENCES}

Barile, M. F., Hopps, H. E. \& Grabowski, M. (1978). Incidence and sources of mycoplasma contamination: a brief review. In Mycoplasma Infection of Cell Cultures, pp. 35-45. Edited by G. J. McGarrity, D. G. Murphy \& W. W. Nichols. New York \& London: Plenum Press.

Butler, M. \& KNight, B. C. J. G. (1960). The survival of washed suspensions of mycoplasma. Journal of General Microbiology 22, 470-477.

Chen, T. A. \& Liao, C. H. (1975). Corn stunt spiroplasma: isolation, cultivation and proof of pathogenicity. Science 188, 1015-1017.

ChIU, R. J. \& BlacK, L. M. (1967). Monolayer cultures of insect cell lines and their inoculation with a plant virus. Nature, London 215, 1076-1078.

Clyde, W. A. (1964). Mycoplasma species identification based upon growth inhibition by specific antisera. Journal of Immunology 92, 958-965.

Cole, R. M., Tully, J. G., Popkin, T. J. \& Bové, J. M. (1973). Morphology, ultrastructure and bacteriophage infection of the helical mycoplasma-like organism (Spiroplasma citri, gen.nov., sp.nov.) cultured from 'stubborn' disease of citrus. Journal of Bacteriology 115, 367-386.

Cotty, P. J. \& Chen, T. A. (1979). Spiroplasma growth factors from chloroform extracted horse serum. Phytopathology 69, 1025.

Davis, R. E. (1979). Spiroplasmas: newly recognised arthropod-borne pathogens. In Leafhopper Vectors and Plant Disease Agents, pp. 451-484. Edited by K. Maramorosch \& K. F. Harris. New York \& London: Academic Press.

Davis, R. E., Lee, I. M. \& Basciano, L. K. (1979). Spiroplasmas: serological groupings of strains associated with plants and insects. Canadian Journal of Microbiology 25, 861-866.

Dollet, M., Saillard, C., Garcia-Jurado, O., Vignault, J. C., Gargani, D., Tully, J. G. \& Bové, J. M. (1980). An approach to the serological study of the mycoplasmas of lethal yellowing in the coconuts in West Africa. In Proceedings of the 4th Meeting of the International Council on Lethal Yellowing, 1979, p. 8. University of Florida Publication FL-80-1.

Eden-Green, S. J. (1978). Attempts to extract and culture mycoplasmas from coconut palms. In Proceedings of the 3rd Meeting of the International Council on Lethal Yellowing, 1977, p. 20. University of Florida Publication FL-78-2.

EDEN-Green, S. J. \& Tully, J. G. (1979). Isolation of Acholeplasma spp. from coconut palms affected by lethal yellowing disease in Jamaica. Current Microbiology 2, 311-316.

Eden-Green, S. J., Markham, P. G. \& Townsend, R. (1980). Acholeplasmas and lethal yellowing disease II. Transmission experiments. In Proceedings of the 4th Meeting of the International Council on Lethal Yellowing, 1979, pp. 10-11. University of Florida Publication FL-80-1.

Freundt, E. A., Andrews, B. E., Ernø, H., Kunze, M. \& BLACK, F. T. (1973). The sensitivity of Mycoplasmatales to sodium-polyanethol-sulphonate and digitonin. Zentralblatt für Bakteriologie, Parasitenkunde, Infektionskrankheiten und Hygiene (Abteilung I, Originale A) 225, 104-112.

GrYlls, N. E. \& Hunt, P. (1971). A review of the study of the aetiology of coconut lethal yellowing disease. Oléagineux 26, 311-315.

HAYFLICK, L. (1965). Tissue cultures and mycoplasmas. Texas Reports on Biology and Medicine 23, 285-303.

INTERNATIONAL COMMITTEE ON SYSTEMATIC BACTERIOLOGY, SUBCOMMITTEE ON THE TAXONOMY of Mollicutes. (1979). Proposal of minimal standards for descriptions of new species of the class Mollicutes. International Journal of Systematic Bacteriology 29, 172-180.

Junca, P., Saillard, C., Tully, J., Garcia-Jurado, O., DEgORCE-Dumas, J.-R., MOUChes, C., Vignault, J.-C., Vogel, R., McCoy, R., Whitcomb, R., Williamson, D., LATRILle, J. \& Bové, J. M. (1980). Caractérisation de spiroplasmes isolés d'insectes et de fleurs de France continentale, de Corse et du Maroc; proposition pour une classification de spiroplasmes. Comptes rendus hebdomadaires de séances de l'Academie des sciences D290, 1209-1212.

Kondo, F., Maramorosch, K., McIntosh, A. H. \& VARNEY, E. H. (1977). Aster yellows spiroplasma: isolation and cultivation in vitro. Proceedings of the American Phytopathological Society 4, 190-191.

Markham, P. G. \& Townsend, R. (1979). Experimental vectors of spiroplasmas. In Leafhopper Vectors and Plant Disease Agents, pp. 413-445. Edited by K. Maramorosch \& K. F. Harris. New York \& London: Academic Press.

Markham, P. G., Townsend, R., Bar-Joseph, M., Daniels, M. J., Plaskitt, A. \& Meddins, B. M. (1974). Spiroplasmas are the causal agents of citrus little leaf disease. Annals of Applied Biology 78, 49-57. 
Markham, P. G., Townsend, R., Plaskitt, K. \& Saglio, P. (1977). Transmission of corn stunt to dicotyledonous plants. Plant Disease Reporter 61, 342-345.

McCoy, R. E. (1978). Attempts to culture mycoplasmalike agents at Fort Lauderdale. In Proceedings of the 3rd Meeting of the International Council on Lethal Yellowing, 1977, p. 20. University of Florida Publication FL-78-2.

McCoy, R. E. (1979). Mycoplasmas and yellows diseases. In The Mycoplasmas, vol. 3, pp. 229-264. Edited by R. F. Whitcomb \& J. G. Tully. New York \& London: Academic Press.

NylaNd, G. \& RaJU, B. C. (1978). Isolation and culture of a spiroplasma from pear trees affected by pear decline. Phytopathology News 12, 216.

RaJu, B. C. \& NYlaND, G. (1978). Effects of different media on the growth and morphology of three newly isolated plant spiroplasmas. Phytopathology News $12,216$.

Raju, B. C., Purcell, A. H. \& Nyland, G. (1980). Isolation of spiroplasmas from leafhoppers exposed to aster yellows and $\mathrm{X}$ disease. In Proceedings of the 4th Meeting of the International Council on Lethal Yellowing, 1979, p. 12. University of Florida Publication FL-80-1.

Saglio, P., Laflèche, D., Bonissol, C. \& Bové, J. M. (1971). Isolement, culture et observation au microscope électronique des structures de type mycoplasme associées à la maladie du Stubborn des agrumes et leur comparaison avec les structures observées dans le cas de la maladie du Greening des agrumes. Physiologie végétale 9, 569-582.

Saglio, P., L'Hospital, M., Laflèche, D., Dupont, G., Bové, J. M., Tully, J. G. \& Freundt, E. A. (1973). Spiroplasma citri gen. and sp.n.: a mycoplasma-like organism associated with 'Stub- born' disease of citrus. International Journal of Systematic Bacteriology 23, 191-204.

Townsend, R., Markham, P. G. \& Plaskitt, K. A. (1977). Multiplication and morphology of Spiroplasma citri in the leafhopper Euscelis plebejus. Annals of Applied Biology 87, 307-313.

Townsend, R., Eden-Green, S. J., Markham, P. G., ARCher, D. \& Clark, M. F. (1980). Acholeplasmas and lethal yellowing disease III. Microbiological and serological studies. In Proceedings of the 4th Meeting of the International Council on Lethal Yellowing, 1979, p. 11. University of Florida Publication FL-80-1.

Tully, J. G., Rose, D. L., Garcia-Jurado, O., Vignault, J.-C., Saillard, C., Bové, J. M., McCoy, R. E. \& Williamson, D. L. (1980). Serological analysis of a new group of spiroplasmas. Current Microbiology 3, 369-372.

Waters, H. \& HuNT, P. (1980). The in vivo three-dimensional form of a plant mycoplasma-like organism by the analysis of serial ultrathin sections. Journal of General Microbiology 116, 111-131.

Whitcoms, R. F. \& Williamson, D. L. (1975). Helical wall-free prokaryotes in insects: multiplication and pathogenicity. Annals of the New York Academy of Sciences 266, 260-275.

Williamson, D. L. \& Whitcomb, R. F. (1975). Plant mycoplasmas: a cultivable spiroplasma causes corn stunt disease. Science 188, 1018-1020.

Williamson, D. L., Whitcomb, R. F. \& Tully, J. G. (1978). The spiroplasma deformation test, a new serological method. Current Microbiology 1, 203-207.

Williamson, D. L., Tully, J. G. \& Whitcomb, R. F. (1979). Serological relationships of spiroplasmas as shown by combined deformation and metabolic inhibition tests. International Journal of Systematic Bacteriology 29, 345-351. 